\title{
Effects of public policy on the fragmentation of the Swedish education system and its impact on cultural diversity
}

\author{
Efectos de la política pública en la fragmentación del sistema educativo sueco \\ y su impacto en la diversidad cultural
}

Dina Bern

Faculty of Language Sciences, Education and Communications International Iberoamerican University, Arecibo, Puerto Rico bern.unini@gmail.com

Fecha recepción: 12/05/2020

Páginas 84-97

Fecha aceptación: 29/05/2020

\begin{abstract}
.
Varied studies conclude that decentralization fragmented the Swedish education system and undermined cultural diversity. Evidence is the increasing inequality, segregation, and performance reduction of students of vulnerable groups. The study aims at finding out how public policy undermines the education system; the Swedish Agency of Education's measures to stop the damage; whether teacher perception harms cultural diversity; and if suggestions to improve the system and cultural diversity would be welcomed. Method: Mixed. Design: Sequential Exploratory. Modality: Comparative and Derivative. Instrument: A five-dimensions Likert scale created ad hoc for the study and validated by expert judgment, and a semi structured interview. Participants: 423 teachers and five principals. The Kolmogorov-Smirnov normality and hypothesis test merited a Spearman rho test. Results: There is an unfavorable perception of cultural diversity among the respondents. Example. Respondents agree that diverse teachers benefit diverse students because they represent role models. However, respondents do not want diverse teachers in their schools. The principals show similar results. Education might not be the only target of public policy.
\end{abstract}

Keywords: decentralization, teachers' perception, cultural diversity

\section{Resumen.}

Diversos estudios llegan a la conclusión de que la descentralización fragmentó el sistema educativo sueco y socavó la diversidad cultural. La prueba es el aumento de la desigualdad, la segregación y la reducción del rendimiento de los estudiantes de los grupos vulnerables. El estudio tiene por objeto determinar la forma en que la política pública socava el sistema educativo; las medidas del Organismo Sueco de Educación para detener el daño; si la percepción de los maestros perjudica la diversidad cultural; y si se acogerían con beneplácito las sugerencias para mejorar el sistema y la diversidad cultural. Método: Mixto. Diseño: Exploratorio secuencial. Modalidad: Comparativa y Derivada. Instrumento: Una escala Likert de cinco dimensiones creada ad hoc para el estudio y validada por el juicio de los expertos, también se utilizo una entrevista semiestructurada. Participantes: 423 profesores y cinco 
directores. La prueba de normalidad e hipótesis se realizo a través de Kolmogorov-Smirnov mereció una prueba de rho de Spearman. Resultados: Hay una percepción desfavorable de la diversidad cultural entre los encuestados. Ejemplo. Los encuestados están de acuerdo en que la diversidad de los profesores beneficia a los estudiantes porque representan modelos a seguir. Sin embargo, los encuestados no quieren profesores diversos en sus escuelas. Los directores muestran resultados similares. La educación podría no ser el único objetivo de la política pública.

Palabras clave: descentralización, percepción de los docentes, diversidad cultural

\section{1.-Introducción.}

National and international investigations state that the public policy of decentralization caused the fragmentation of the Swedish education system. The damage to the school system has extended to factors encompassed by cultural diversity. This is obvious in statements by international actors such as the Organization for Economic Cooperation and Development in its report Improving Schools in Sweden: An OECD Perspective: "a healthy education system allows its students to achieve high-level skills and knowledge according to their ability and motivation, not according to their socioeconomic background "(2015, p. 3), and in declarations by national actors, such as the former minister of education, who describes the current state of the education system as a political failure because the socioeconomic situation, origin and educational background of the parents are increasingly revealed by the grades of the students. The OECD's report (2015) even includes recommendations to improve the education system through better professional development for teachers, principals and other school administrators so that they can provide quality education to all the students. UNICEF's report entitled An unfair star - Inequality in children's education in rich countries (2018) consists of surveys in $41 \mathrm{EU}$ and OECD countries to analyze the connection between parents' backgrounds and student outcomes, as well as other factors such as performance in relation to the gender of the students. About the results, the person responsible for UNICEF Sweden stated that she was not surprised because it is well known, even in Sweden, that the country does not have a school system that treats people equally, and declared that what is needed is political action. The Swedish government which started work in early 2019 launched a new education plan that was criticized by the president of one of the teachers' unions. She emphasized that the Swedish Education Agency has stated that the schools have three serious problems: inequality, lack of teachers and segregation, but segregation is not even mentioned in the new education plan. The president sees this as a betrayal to the teachers, principals, and students who struggle daily in a segregated school system (Wallin and Sandberg, 2019).

\section{1.-Decentralization, privatization and the right to choose a school.}

Shirley (2017, pp. 40-41) confirms that the government policies or reforms that have caused the decline of the Swedish educational system are of a neoliberal capitalist nature and that it is surprising that they were introduced by the Social Democrats. This fact could be described as paradoxical since the Swedish welfare state was founded precisely by the Social Democratic party. The reforms, which resulted from affinities with globalizing policies and which impacted the education system were introduced in the early 1990s during an election 
period. Supposedly the Social Democrats initiated the changes aiming at preventing the conservatives from winning the elections (Ibid., P. 40).

The first step of the decentralization of the school system consisted in that the State transferred responsibility of the education to the municipalities. More specifically, elementary, secondary and adult education, as well as the full financial responsibility of the schools that offer such education, although the funds come from the State. The second step, privatization, which includes the right to choose school, was taken by those in charge of implementing political measures following the arguments and instructions of neoclassic economists interested in applying the principles of market competition to public institutions ( Ibid.). When the second reform began, that is, privatization and the right to choose school, there were around 60 private schools in the country. In less than 20 years the number increased to 709 (Shirely, 2017, p. 41). The current number is about 900 . The increase in the number of private schools and the right to choose school effectively ended the policy of attendance. The policy of attendance's job was to direct the students of a neighborhood to the schools they should attend. This was detrimental to the education system and affected society in general. It created, for example, internalization of market ideologies in families, decrease in the quality of the teachers' working conditions and in the quality of the training of teacher and principals. It also provoked adverse effects on cultural diversity and increased inequality and segregation. The detrimental factors do not remain in the education system. Inequality at school is an example. It creates disadvantage and steals opportunities from people when they reach adulthood, subjecting them to marginalization (UNICEF, 2018).

Slowly but surely the private schools managed by private business actors replaced the "school for all". Private schools are also known as independent or free schools (fria skolor in Swedish). The term independent or free schools possibly refers to the fact that their functions are rather autonomous and that they are not part of the education system to which public schools belong. They are like the charter schools of the US and the academies of England (Shirely, 2017, p. 40).

\section{2.-Political guidelines sometimes do not have democratic representation.}

According to Rivas Flores, (2004, p. 41) political guidelines are due to consensuses that control representative democracies, but sometimes these derive from social and economic forces without democratic representation or respond only to international political demands.

Antunes (2006, p. 39) quotes Dale (1999, 2000a, 2000b) and Antunes (2001) to explain that, although the structure of national educational policy agendas is global, the effects of globalization on education are caused by the State, its position at global level, and its social, political, and national institutional relations and interactions National educational policies conform to global agendas that define priorities in social training, mobilization of resources and the solutions that are chosen and applied. The options of the States may be few, but the actions that the States take are vital to adjust and regulate international agendas and to define education policies at national level (Ibid.). The authors' arguments seems to coincide with the findings of Lawn and Lingard (2002), whose investigation shows that Finland has one of best education systems in the western hemisphere thanks to the fact that the Finish government adjusted the global education agendas to their population, while Sweden did the opposite. 


\section{3.-The teachers' perception of cultural diversity.}

Is the teachers' perception of cultural diversity related to the lack of progress in improving the system and the growing inequality that permeate it? Various investigations maintain that the Swedish education system and cultural diversity were harmed by public policy. The inequality that currently characterizes the school system undermines cultural diversity. Do teachers and their perception of cultural diversity have something to do with the marked decrease in student performance and achievement? The important findings of researchers in this regard must be considered.

Carlgren and Klette (2008, in Nilsson Lindström and Beach, 2015, p. 251) report that politicians have created a new type of teacher to work in the decentralized education system. It consists of "service-minded, flexible teachers receptive to the demands of the market at the cost of their professional judgment, ethics and autonomy." This is because the role of the students and their parents have changed. They are now clients who see the teachers as subordinates. As such, the teachers, and increasingly also the principals, must do what the clients demand to keep them satisfied.

It seems, then, that the decline in the quality of teacher training programs has been intentional. The new client role of the students and their parents has not only changed their relationship with the teachers, but with everything that concerns the school. Since the schools do not want to lose their clients, they do as their clients say and want because the market demands that the clients be satisfied.

Taking the above into consideration, it is possible that consciously or unconsciously teachers with a market-friendly frame of mind and ideas, or who simply want to keep their job by following the instructions of their employers, could harm the education system as well as cultural diversity.

\section{2.-Methodology.}

2.1.-About the method, design, and modality.

Method: Mixed. Design: Sequential Exploratory. Modality: Comparative and Derivative.

\section{2.-About the instruments.}

The quantitative part of the study was carried out by collecting the data with a Likert-type survey $(1=$ strongly disagree; 2 = disagree; $3=$ undecided $/$ do not know; $4=$ agree; $5=$ strongly agree). The instrument consists of 31 items and was created ad hoc for the investigation (which is in the process of being printed). It was validated by expert judgment. Some of the constructs/items were inspired by Hsiao (2015), Cachon (2005/2006), Grossman (in James, 2004) and Banks. The items of the quantitative instrument were reversed from 5 to 1 (instead of 1 to 5), except for item 15. The final numerical order of the items on the survey sent to the teachers varies slightly from the order stipulated on the Operationalization Table. The reason is that the order on the Operationalization Table could have informed the participants about the exact topics under investigation, which had the potential of affecting their responses. 
The qualitative part of the study was carried out by collecting information with a semi structured interview consisting of 15 constructs from the scale.

\section{3.-Population and sample.}

The total population from which the sample was drawn consists of around 267,000 primary and secondary teachers, all active in public and independent schools (aka private and free schools) in the country. But there are some who insist that the total population of teachers is 285,000 . For the purposes of this work, the total number of the population of teachers was reached by analyzing articles published in national newspapers.

\section{4.-Sample Selection.}

The sample selection was intentional and criterial. All primary and secondary teachers active in public and independent schools (free and private) in different regions of the country. Since it was not possible to obtain statistics about the age of the teachers chosen for the sample, or the number of years they have been working within the Swedish education system, boxes or lines to provide this information were made available in the quantitative instrument. The same was done with the qualitative instrument.

\section{5.-Participants.}

423 teachers of grammar and secondary school from several Swedish regions and five principals from three different regions. The participation of the principals was obtained by way of contacting the heads of education departments in different regions.

\section{6.-Procedure.}

The quantitative data collection instrument (the scale) was made available to over 5,000 teachers from various Swedish regions as follows: An invitation to participate in the study was sent by email to the teachers in the schools from where the sample was obtained. A brief presentation of the researcher and a brief explanation of the study were attached to the invitation, as well as the website and the link to access and answer the survey. The effort yielded 423 participants. The participation of the principals was obtained through the same procedure, but only after several heads of education departments from different regions intervened.

\section{3.-Results.}

Only the most relevant to the study's objective will be shown. These are the responses to the statements on Cultural Diversity (Dimension D), and to the statements with suggestions that would result in the improvement of the education system and cultural diversity (Dimension E). For this, it is necessary to start with the part of the Operationalization Table (Table 1) which contains the specific objectives and the statements of both dimensions. 
Table 1.-Operationalization Table.

\begin{tabular}{|c|c|c|}
\hline $\begin{array}{l}\text { SPEFICIFC } \\
\text { OBJECTIVES }\end{array}$ & DIMENSIONS & $\begin{array}{l}\text { ITEMS } \\
1 \text { strongly disagree } \\
2 \text { disagree } \\
3 \text { undecided/do not know } \\
4 \text { agree } \\
5 \text { strongly agree }\end{array}$ \\
\hline $\begin{array}{l}\text { Identify the } \\
\text { characteristics } \\
\text { of cultural } \\
\text { diversity. }\end{array}$ & $\begin{array}{l}\text { D.-CULTURAL } \\
\text { DIVERSITY }\end{array}$ & $\begin{array}{l}\text { D19.- The number of teachers with different cultural } \\
\text { backgrounds should reflect the number of students from } \\
\text { different cultures. } \\
\text { D20.- The curriculum, thematic units and course literature } \\
\text { must contain material that reflects the culture of all the } \\
\text { students in the classroom. } \\
\text { D21.- Teachers must be able to assess the knowledge, } \\
\text { strengths, weaknesses and development needs of students } \\
\text { from different cultures. } \\
\text { D22.- Too much emphasis on diversity reduces the quality } \\
\text { of education. } \\
\text { D23.- The education of the } 21 \text { st century requires } \\
\text { knowledge about cultural diversity. } \\
\text { D24.- In order not to impede the progress of students in the } \\
\text { dominant culture, the segregation of students from different } \\
\text { cultures is appropriate. }\end{array}$ \\
\hline $\begin{array}{l}\text { Suggest } \\
\text { measures to } \\
\text { improve } \\
\text { cultural } \\
\text { diversity and } \\
\text { at the same } \\
\text { the } \\
\text { educational } \\
\text { system. }\end{array}$ & $\begin{array}{l}\text { E.- } \\
\text { SUGGESTIONS } \\
\text { TO IMPROVE } \\
\text { CULTURAL } \\
\text { DIVERSITY AND } \\
\text { THE } \\
\text { EDUCATION } \\
\text { SYSTEM }\end{array}$ & $\begin{array}{l}\text { E25.- Teachers with knowledge of Culturally Relevant } \\
\text { Teaching ensure that their culturally different students strive } \\
\text { to achieve academic excellence. } \\
\text { E26.- Teachers from different cultures benefit students } \\
\text { from different cultures because they represent role models. } \\
\text { E27.- Teachers from majority cultures ensure that the } \\
\text { students from different cultures absorb the majority's } \\
\text { culture. } \\
\text { E28.- All teacher training must include Culturally Relevant } \\
\text { Pedagogy. } \\
\text { E29.- Students from other cultures perform better when } \\
\text { their education is carried out with their culture as a starting } \\
\text { point. } \\
\text { E30.- Students from other cultures learn best when their } \\
\text { education is carried out only with the majority culture as a } \\
\text { starting point. } \\
\text { E31.- The absence of education on Culturally Relevant } \\
\text { Pedagogy in teacher training programs is behind the low } \\
\text { performance and failure of many culturally different } \\
\text { students. }\end{array}$ \\
\hline
\end{tabular}

Own source.

The SPSS software program was used. First, the Kolmogorov-Smirnov test for normality and hypothesis testing was applied to the data. The result informed that the distribution was not normal. This test was followed by the Spearman's rho because, if the distribution is not normal, the Pearson's $p$ is not applicable. The K-S was split to show the results of Dimensions $D$ and $E$ in this article. Unfortunately, the extension of the Spearman's (rho) correlation test does not allow any divisions and its results for the Dimensions $D$ and $E$ cannot be shown here. 
Table 2.-Summary of hypothesis tests, Dimensions D \& E-

\begin{tabular}{|c|c|c|c|c|c|}
\hline \multicolumn{6}{|c|}{ group_D } \\
\hline & & Frecuencia & Porcentaje & $\begin{array}{c}\text { Porcentaje } \\
\text { válido }\end{array}$ & $\begin{array}{l}\text { Porcentaje } \\
\text { acurnulado }\end{array}$ \\
\hline \multirow[t]{23}{*}{ Válido } & 1,000000 & 1 & .2 & 2 & 2 \\
\hline & 2,000000 & 4 & 9 & .9 & 1,2 \\
\hline & 2,166667 & 7 & 1,7 & 1,7 & 2,8 \\
\hline & 2,333333 & 16 & 3,8 & 3,8 & 6,6 \\
\hline & 2,500000 & 19 & 4,5 & 4,5 & 11,1 \\
\hline & 2,666667 & 30 & 7,1 & 7,1 & 18,2 \\
\hline & 2,750000 & 1 & 2 & 2 & 18,5 \\
\hline & 2,800000 & 1 & 2 & 2 & 18,7 \\
\hline & 2,833333 & 51 & 12,1 & 12,1 & 30,8 \\
\hline & 3,000000 & 58 & 13,7 & 13,7 & 44,5 \\
\hline & 3,166667 & 62 & 14,7 & 14,7 & 59,2 \\
\hline & 3,200000 & 1 & .2 & 2 & 59,5 \\
\hline & 3,333333 & 62 & 14,7 & 14,7 & 74,2 \\
\hline & 3,400000 & 1 & 2 & 2 & 74,4 \\
\hline & 3,500000 & 43 & 10,2 & 10,2 & 84,6 \\
\hline & 3,666667 & 29 & 6,9 & 6,9 & 91,5 \\
\hline & 3,833333 & 18 & 4,3 & 4,3 & 95,7 \\
\hline & 4,000000 & 9 & 2,1 & 2,1 & 97,9 \\
\hline & 4,166667 & 6 & 1,4 & 1.4 & 99,3 \\
\hline & 4,333333 & 1 & .2 & 2 & 99,5 \\
\hline & 4,500000 & 1 & .2 & .2 & 99,8 \\
\hline & 4,666667 & 1 & 2 & .2 & 100,0 \\
\hline & Total & 422 & 99,8 & 100,0 & \\
\hline Perdidos & Sistema & 1 & .2 & & \\
\hline Total & & 423 & 100,0 & & \\
\hline
\end{tabular}

Null bypothesis

Test

Sig

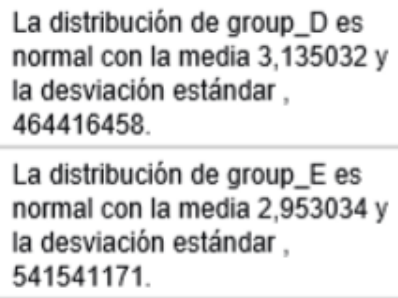

Prueba de Kolmogorov-Smirnov para una muestra

Decision: Reject the null hypothesis.

Own source.

The Table 3 shows the results of the descriptive statistics analyses of the participants' responses to the items of Dimension D. Figure 1 represents the graphics of same.

Table 4 shows the results of descriptive statistics analyses of the participants' responses to the items of Dimension E. Figure 2 represents the graphics of same.

The table and graphic of Dimension E will be followed by explanations and propositions of the meaning of the participants' responses. 
Table 3.-Descriptive statistics of Group D.

Figure 1.-Graphic of the participants' responses to the items of Dimension D.

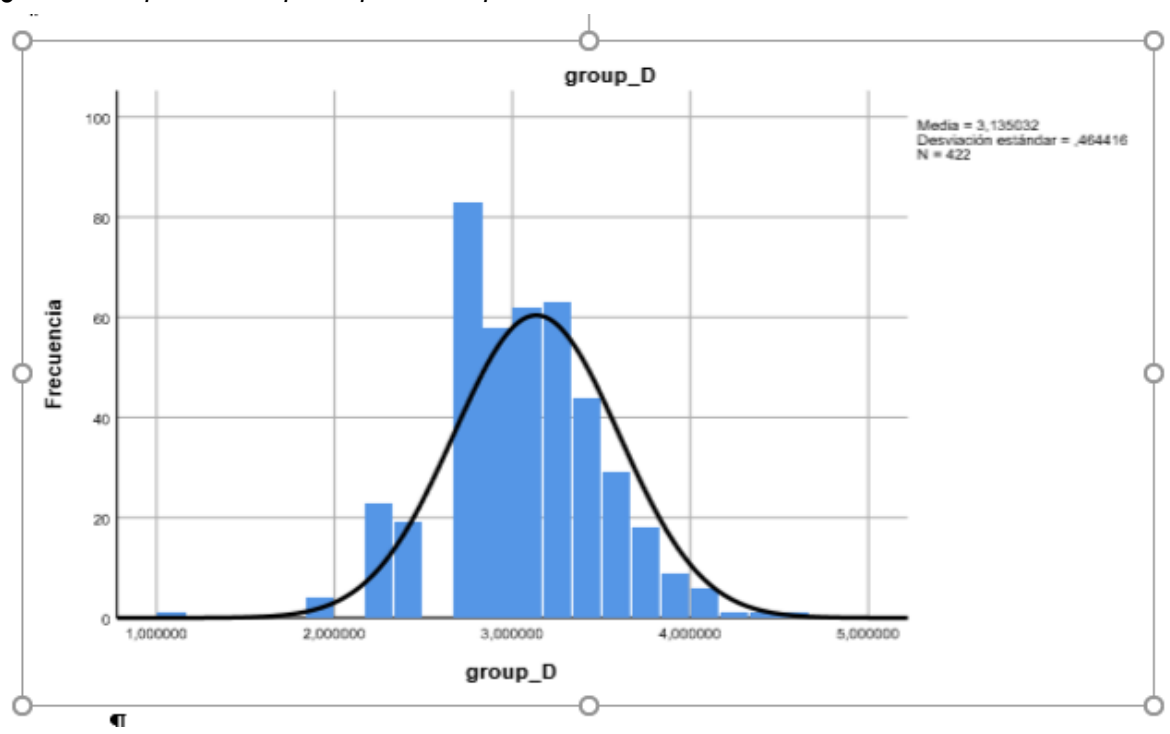

Own source.

Table 4..Descriptive statistics of Group E.

\begin{tabular}{|c|c|c|c|c|c|}
\hline \multicolumn{6}{|c|}{ group_E } \\
\hline & & Frecuencia & Porcentaje & $\begin{array}{l}\text { Porcentaje } \\
\text { válido }\end{array}$ & $\begin{array}{l}\text { Porcentaje } \\
\text { acumulado }\end{array}$ \\
\hline \multirow[t]{25}{*}{ Válido } & 1,333333 & 2 & 5 & .5 & .5 \\
\hline & 1,500000 & 6 & 1,4 & 1,4 & 1,9 \\
\hline & 1,666667 & 6 & 1,4 & 1,4 & 3,3 \\
\hline & 1,833333 & 5 & 1,2 & 1,2 & 4,5 \\
\hline & 2,000000 & 5 & 1,2 & 1,2 & 5,7 \\
\hline & 2,166667 & 19 & 4,5 & 4,5 & 10,2 \\
\hline & 2,333333 & 26 & 6,1 & 6,1 & 16,3 \\
\hline & 2,500000 & 26 & 6,1 & 6,1 & 22,5 \\
\hline & 2,666667 & 36 & 8,5 & 8,5 & 31,0 \\
\hline & 2,833333 & 49 & 11,6 & 11,6 & 42,6 \\
\hline & 3,000000 & 67 & 15,8 & 15,8 & 58,4 \\
\hline & 3,166667 & 44 & 10,4 & 10,4 & 68,8 \\
\hline & 3,200000 & 1 & .2 & ,2 & 69,0 \\
\hline & 3,250000 & 1 &, 2 & 2 & 69,3 \\
\hline & 3,333333 & 56 & 13,2 & 13,2 & 82,5 \\
\hline & 3,500000 & 30 & 7,1 & 7,1 & 89,6 \\
\hline & 3,600000 & 1 &, 2 & 2 & 89,8 \\
\hline & 3,666667 & 18 & 4,3 & 4,3 & 94,1 \\
\hline & 3,750000 & 1 &, 2 & 2 & 94,3 \\
\hline & 3,833333 & 16 & 3,8 & 3,8 & 98,1 \\
\hline & 4,000000 & 2 &, 5 & .5 & 98,6 \\
\hline & 4,166667 & 4 & 9 & 9 & 99,5 \\
\hline & 4,333333 & 1 & 2 & 2 & 99,8 \\
\hline & 4,500000 & 1 & 2 & 2 & 100,0 \\
\hline & Total & 423 & 100,0 & 100,0 & \\
\hline
\end{tabular}

Own source. 
Figure 2.-Graphic of the participants' responses to the items of Dimension E.

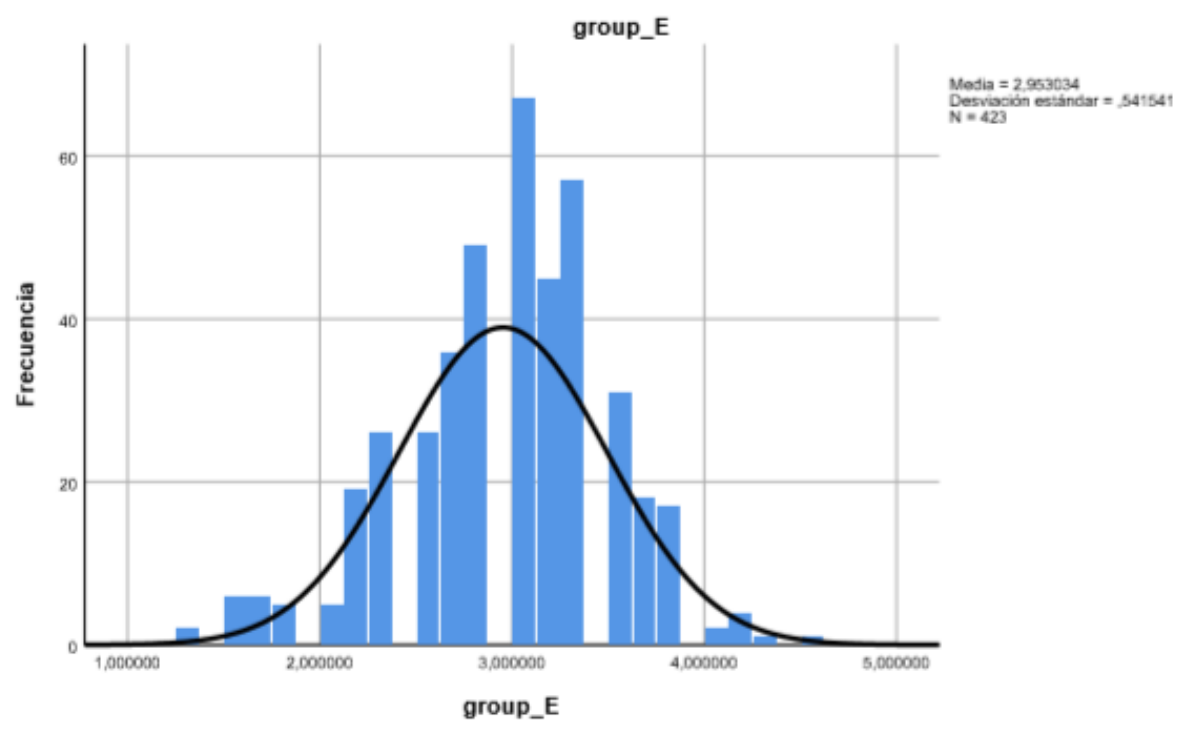

Own source.

It must be added that the answers of the participants prompted a division according to the number of years that they had been working within the education system. The following table is the result. It includes answers to all the dimensions, not only dimensions $\mathrm{D}$ and $\mathrm{E}$. 
Table 5.-Respondent teachers according to years of service within the school system.

\begin{tabular}{|c|c|c|c|c|c|}
\hline $\begin{array}{l}\text { Item } \\
\text { No. }\end{array}$ & $\begin{array}{l}\mathrm{N}=\text { No. participants. } \\
+=13-46 \text { yrs. work } \\
-=0-12 \text { yrs. work }\end{array}$ & $\begin{array}{l}\text { Value } \\
\text { given } \\
\mathbf{N} ;+;-\end{array}$ & $\begin{array}{l}\text { Frequency } \\
\qquad \mathbf{N} ;+;-\end{array}$ & $\begin{array}{c}\text { Valid Pct. } \\
\text { N; +; - }\end{array}$ & $\begin{array}{c}\text { Median } \\
\mathrm{N} ;+;-\end{array}$ \\
\hline 1 & N $423 ;+217 ;-197$ & $1 ; 1 ; 3$ & $167 ; 109 ; 104$ & $39.48 ; 50.23 ; 52.79$ & $2.00 ; 1.00 ; 3.00$ \\
\hline 2 & N $423 ;+217 ;-197$ & $1 ; 1 ; 1$ & $197 ; 124 ; 70$ & $46.57 ; 57.14 ; 35.53$ & $2.00 ; 1.00 ; 2.00$ \\
\hline 3 & N $423 ;+217 ;-197$ & $3 ; 1 ; 3$ & $161 ; 89 ; 89$ & $38.06 ; 41.01 ; 45.18$ & $2.00 ; 2.00 ; 2.13$ \\
\hline 4 & N $423 ;+217 ;-197$ & $1 ; 1 ; 1$ & $178 ; 103 ; 72$ & $42.08 ; 47.47 ; 36.55$ & $2.00 ; 2.00 ; 2.00$ \\
\hline 5 & N $423 ;+217 ; 197$ & $4 ; 4 ; 4$ & $201 ; 105 ; 91$ & $47.52 ; 48.39 ; 46.19$ & $4.00 ; 4.00 ; 4.00$ \\
\hline 6 & N $423 ;+217 ;-197$ & $3 \& 4 ; 3 ; 4$ & 147 ea; $85 ; 79$ & 34.75 ea; $39.17 ; 40.10$ & $3.00 ; 3.00 ; 4.00$ \\
\hline 7 & N 423; + 217; -197 & $3 ; 3 ; 3$ & $218 ; 97 ; 117$ & $51.54 ; 44.70 ; 59.39$ & $3.00 ; 3.00 ; 3.00$ \\
\hline 8 & N $423 ;+217 ;-197$ & $1 ; 1 ; 1$ & $201 ; 109 ; 87$ & $47.52 ; 50.23 ; 44.16$ & $2.00 ; 1.00 ; 2.00$ \\
\hline 9 & $\mathrm{~N} 423 ;+217 ;-197$ & $1 ; 1 ; 1$ & $230 ; 123 ; 99$ & $54.37 ; 56.68 ; 50.25$ & $1.00 ; 1.00 ; 1.00$ \\
\hline 10 & N 423; + 217; -197 & $4 ; 2 ; 4$ & $138 ; 75 ; 68$ & $32.62 ; 17.05 ; 34.52$ & $3.00 ; 2.00 ; 4.00$ \\
\hline 11 & N $423 ;+217 ;-197$ & $3 ; 3 ; 3$ & $300 ; 155 ; 140$ & $70.92 ; 71.43 ; 71.07$ & $3.00 ; 3.00 ; 3.00$ \\
\hline 12 & N $423 ;+217 ;-197$ & $2 ; 2 ; 4$ & $136 ; 82 ; 56$ & $32.15 ; 37.79 ; 28.43$ & $3.00 ; 2.00 ; 3.00$ \\
\hline 13 & N $423 ;+217 ;-197$ & $3 ; 3 ; 3$ & $156 ; 79 ; 75$ & $36.88 ; 36.41 ; 38.07$ & $3.00 ; 3.00 ; 3.00$ \\
\hline 14 & N $423 ;+217 ;-197$ & $4 ; 4 ; 4$ & $209 ; 123 ; 82$ & $49.41 ; 56.68 ; 41.62$ & $4.00 ; 4.00 ; 4.00$ \\
\hline 15 & N $423 ;+217 ;-197$ & $2 ; 2 ; 2$ & $144 ; 76 ; 66$ & $34.04 ; 35.02 ; 33.50$ & $3.00 ; 3.00 ; 3.00$ \\
\hline 16 & N $423 ;+217 ;-197$ & $4 ; 4 ; 4$ & $183 ; 104 ; 76$ & $43.26 ; 47.93 ; 38.58$ & $4.00 ; 4.00 ; 4.00$ \\
\hline 17 & N 423; + 217; -197 & $4 ; 5 ; 4$ & $175 ; 100 ; 79$ & $41.37 ; 46.08 ; 40.10$ & $4.00 ; 4.00 ; 4.00$ \\
\hline 18 & N $423 ;+217 ;-197$ & $4 ; 4 ; 4$ & $161 ; 84 ; 74$ & $38.06 ; 38.71 ; 37.56$ & $4.00 ; 4.00 ; 4.00$ \\
\hline 19 & $\mathrm{~N} 423 ;+217 ;-197$ & $4 ; 4 ; 2$ & $113 ; 60 ; 53$ & $26.71 ; 27.65 ; 26.90$ & $3.00 ; 3.00 ; 2.00$ \\
\hline 20 & N $423 ;+217 ;-197$ & $4 ; 4 ; 4$ & $158 ; 75 ; 80$ & $37.35 ; 34.56 ; 40.61$ & $3.00 ; 3.00 ; 3.00$ \\
\hline 21 & $\mathrm{~N} 423 ;+217 ;-197$ & $4 ; 4 ; 4$ & $126 ; 69 ; 57$ & $29.79 ; 31.80 ; 28.93$ & $3.00 ; 3.00 ; 3.00$ \\
\hline 22 & N $423 ;+217 ;-197$ & $5 ; 5 ; 5$ & $241 ; 124 ; 112$ & $56.97 ; 57.14 ; 56.85$ & $5.00 ; 5.00 ; 5.00$ \\
\hline 23 & N $423 ;+217 ;-197$ & $4 ; 4 ; 4$ & $128 ; 65 ; 61$ & $30.26 ; 29.95 ; 30.96$ & $3.00 ; 3.00 ; 3.00$ \\
\hline 24 & N $423 ;+217 ;-197$ & $4 ; 4 \& 5 ; 4$ & $185 ; 97 ; 81$ & $43.74 ; 44.70 ; 41.12$ & $4.00 ; 4.00 ; 4.00$ \\
\hline 25 & N $423 ;+217 ;-197$ & $1 ; 1 ; 1$ & $232 ; 117 ; 111$ & $54.85 ; 53.92 ; 56.35$ & $1.00 ; 1.00 ; 1.00$ \\
\hline 26 & N $423 ;+217 ;-197$ & $1 ; 1 ; 2$ & $131 ; 67 ; 67$ & $30.97 ; 30.88 ; 34.01$ & $2.00 ; 2.00 ; 2.00$ \\
\hline 27 & N $423 ;+217 ;-197$ & $3 ; 3 ; 3$ & $213 ; 106 ; 100$ & $50.35 ; 48.85 ; 50.76$ & $3.00 ; 3.00 ; 3.00$ \\
\hline 28 & N $423 ;+217 ;-197$ & $4 ; 4 ; 3$ & $144 ; 84 ; 66$ & $34.04 ; 38.71 ; 33.50$ & $4.00 ; 4.00 ; 4.00$ \\
\hline 29 & N 423; + 217; -197 & $3 ; 3 ; 3$ & $190 ; 93 ; 94$ & $44.92 ; 42.86 ; 47.72$ & $3.00 ; 3.00 ; 3.00$ \\
\hline 30 & $\mathrm{~N} 423 ;+217 ;-197$ & $1 ; 1 ; 1$ & $178 ; 97 ; 77$ & $42.08 ; 44.70 ; 39.09$ & $2.00 ; 2.00 ; 2.00$ \\
\hline 31 & $\mathrm{~N} 423 ;+217 ;-197$ & $3 ; 3 ; 3$ & $155 ; 81 ; 70$ & $36.64 ; 37.33 ; 35.53$ & $3.00 ; 3.00 ; 3.00$ \\
\hline
\end{tabular}

Own creation 


\section{4.-Conclusions of the study through Dimensions $\mathrm{D}$ and $\mathrm{E}$.}

Yes. There is an unfavorable perception of cultural diversity among the respondents. The inconsistency in their responses dealing with the same theme could indicate ignorance of $21 \mathrm{st}$ century education requirements, perhaps due to questionable professional training. Examples: The Respondents agree that culturally diverse teachers benefit culturally diverse students because they represent role models (item 6 in the scale). However, they do not want the number of diverse teachers to reflect the number of diverse students in schools (item 19 in the scale). Item 20 informs that the curriculum, thematic units and the course literature must contain material that reflects the culture of the students in the classroom. 200 participants agree. But 183 do not agree. The difference is too small to be considered favorable. Item 21 states that students from other cultures obtain better results when their education is carried out with their culture as a starting point. 146 participants agree, but 165 , the majority, do not agree. The rest indicates not to know. The statement of item 23 declares that too much emphasis on diversity reduces the quality of education. Most of the respondents, 181 of them, do not agree. 175 agree. The difference is too small. Item 27 reads, teachers with knowledge of culturally relevant teaching ensure that their culturally different students strive for academic excellence. Most of the respondents, 213 of them, indicate not knowing. Most of the participants do not agree with item 31, which reads: the absence of education on culturally relevant pedagogy in teacher training programs is the cause of the low performance and failure of many culturally different students. But the inconsistency in their answers imply that they possibly lack this knowledge.

It must be added that the participant principals also show inconsistencies. But Norberg (2019) provides an idea as to why. The author informs that in 2018, according to the government report SOU 2018: 17, the government gave its support to a recommendation for an education program for aspiring directors. It would be a national program, and it would be created in a way that would allow it to be part of the courses offered by the universities to aspiring directors. Also, a revision of the School Law was suggested in order to allow principals and teachers to participate in skills-development courses. From this information from Norberg (2019) we learn not only that directors do not have a university education as such (although they could have other kind of university education), but that teachers and principals as well probably did not attend skills-development program and courses.

However, the investigations consulted for this study indicate that the state of the Swedish education system is not due to some miscalculation or due to mistakes by politicians. The evidence tends to indicate that this is the result of a plan to totally change Swedish society.

Schools are instruments of change and through them changes are made to societies (Sadker and Sadker. 2000, in Vatanartiran and Örücü, 2014, p. 139). And "... for many politicians and policy makers, schools ... are the best solution because through them social changes and reforms can be ensured" (Harris, 2009, Ibid.).

Therefore, neoliberalism in Sweden would be impossible without first capturing the educational system. It is proposed, then, that changes to the education system were not the objective of the decentralization policy. The objective was to use the education system as an instrument to change society. This allowed for the privatization of schools, which has resulted in the now well-known inequality and segregation.

Regarding the teachers, national and international actors argue that their education is of questionable quality and that they are the reason the system is in such sad state. However, 
those within the government in charge of education are the ones responsible for this problem. The education of the teachers has been changed, reformulated and stripped of the qualities that prior to the decentralization, made the Swedish education systems one of the best in the western hemisphere.

As previously informed, after the municipalization of the education system it became necessary to create new programs for the professional training of teachers. The new type of teacher that has been in production by politicians to serve in the decentralized education system is described by Carlgren and Klette (2008, in Nilsson Lindström and Beach, 2015, p. 251), as "teachers with a service mindset, flexible, and responsive to market demands at the cost of their professional judgment, ethics, and autonomy". How has this new type of teacher been obtained? Nilsson Lindström and Beach (2015) report that they carried out a study consisting of identifying, analyzing, comparing and discussing patterns of continuity and discursive change between and within different political texts regulating the objectives, content and examinations of teacher training. They then compared the patterns found with recently found changes in school organization and in the content and control of teacher work. The researchers found specific patterns of change that take away the teachers' control of their profession.

Among the new difficulties for teachers is the marketing of schools. Many of the administrators or those responsible for the schools do not allow disciplining violent or threatening students because the heads of the schools argue that their places of work would be negatively affected. Additionally, students and their parents pressure the teachers to change unsatisfactory grades, and there are examples of principals violating school law by doing so when the teachers refuse. Forcing schools to get rid of their teachers for frivolous reasons has also become a new trend among parents.

The changes caused by public policy on the education system extend to other areas of society, as noted before. But within the education system, even the Swedish Education Agency has clamored for the return of the State for effective control, because the deficiencies arise in primary school and spread through all levels of the system. One of the biggest causes of the problem is that there are not enough competent educators. In some municipalities, most teachers lack university qualifications. Increasing numbers of students are leaving primary school with grades too low to enter upper secondary school. In 2017 in several schools, half of the students in the ninth grade did not get the minimum qualifications to start high school. In addition, many of the students who complete secondary education and are admitted to preparatory programs to begin higher education have such great difficulties that it is sometimes difficult, or impossible, to continue with their studies.

The fact that 187,000 teachers must be recruited full-time by 2031 shows the enormity of the problem. Not many municipalities can meet that requirement. Given the foregoing, the head of secondary education at the Swedish Education Agency insists that the State must once again become responsible for the school system.

It is proposed that the arguments of Rivas Flores (2004, p. 41) and Antunes (2006, p. 39) describe what has happened with the Swedish educational system. First, in line with the arguments of Rivas Flores (Ibid.), the changes to the Swedish educational system derived either from consensus of social and economic forces without democratic representation, or from consensus interested in responding only to international political demands. The second alternative, in line with the arguments of Antunes (2006, p. 39), proposes that, since the State oversees supranational regulation and national educational policy, the State is responsible for the impact of globalization on education. States have few but enough alternatives. In the 
Swedish case, the State did not consider the effects on its population. Its priority focused on responding only to international political demands. It is proposed that the arguments of Rivas Flores (2004, p. 41) and Antunes (2006, p. 39), describe what has happened with the Swedish educational system. First, the changes to the Swedish educational system derived either from forces without democratic representation, or from consensus interested only in responding to international political demands.

The second alternative, in line with the arguments of Antunes (2006, p. 39), proposes that, since the State oversees supranational regulation and national educational policy, the State is responsible for the impact of globalization on education. States have few but enough alternatives. In the Swedish case, the State did not consider the effects on its population. Its priority focused on responding only to international political demands. The arguments of Rivas Flores (2004, p. 41) and Antunes (2006, p. 39) can be seen in the comparison of the effects of national policies with and without adjustments to global policies in Finland and Sweden.

Finland has a successful education system. Sweden has a fragmented educational system. The Finns adjusted the global directives by raising and strengthening general education and by strengthening the education of the gifted because "global competition demands that education pays off". Sweden on the other hand "broke with its past by basing its reason for existing on international competition rather than on its national community". The whole country lost with this decision of the government (Lawn and Lingard, 2002, p. 296).

This indicates that many of the problems of the Swedish education system, including the undermining of cultural diversity, by mistake or by design, are due to lack of adjustments to global policies at national level. It also indicates that any recommendation or suggestion to improve the system and the approach to cultural diversity is not going to be considered favorably if it means changes to the current political designs. The half-responses of those in charge to the recommendations of the OECD (2015) make it clear. Their indifference to the alarming reports about the increasing inequality and segregation in the Swedish schools make it clear as well.

\section{5.-References.}

Antunes, F. (2006). Globalisation and Europeification of Education Policies: routes, processes and metamorphoses. European Educational Research Journal, 5 (1), 38-55.

Lawn, M., y Lingard, B. (2002). Constructing a European policy space in educational governance: the role of transnational policy actors. European Educational Research Journal, 1 (2), 290-307.

Nilsson Lindström, M., y Beach, D. (2015). Changes in Sweden in the neo-liberal education age: Toward an occupation in itself or a profession for itself? Education Inquiry, 6 (3), 241-258.

Norberg, K. (2019). The Swedish national principal training programme: a programme in constant change. Journal of Educational Administration and History, 51 (1), 5-14. DOI:10.1080/00220620.2018.1513912. 
Organization for Economic Co-operation and Development (2015). Improving schools in Sweden: An OECD perspective. Paris: OECD.

Rivas Flores, J.I. (2004). Política educativa y prácticas pedagógicas. Revista de Reflexión Socioeducativa, 4, 36-43.

Shirley, D. (2017). The new imperatives of educational change: achievement with integrity. London: Routledge, Taylor \& Francis Group.

United Nations Children's Fund (2018). An unfair start: Inequality in children's education in rich countries. Florence: UNICEF.

Vatanartiran. S., y Örücü D. (2014). Who drives educational change: school or society? European journal of Business and Social Sciences, 3 (4), pp. 137-148.

Wallin, F., y Sandberg, K. (2019). Efter politiska röran: Så påverkas skolan med nya regeringen. Recovered on April 18, 2019, from https://skolvarlden.se/artiklar/efterpolitiska-roran-sa-paverkas-skolan-med-nya-regeringen 